2. Liu D, Schilling B, Liu D, Sucker A, Livingstone E, Jerby-Arnon L, Zimmer L, Gutzmer R, Satzger I, Loquai C, Grabbe S, Vokes N, Margolis CA, Conway J, He MX, Elmarakeby H, Dietlein F, Miao D, Tracy A, Gogas H, Goldinger SM, Utikal J, Blank CU, Rauschenberg R, von Bubnoff D, Krackhardt A, Weide B, Haferkamp S, Kiecker $F$, Izar B, Garraway L, Regev A, Flaherty K, Paschen A, Van Allen EM, Schadendorf D. Integrative molecular and clinical modeling of clinical outcomes to PD1 blockade in patients with metastatic melanoma. Nat Med 2019;25(12):1916-27.

3. Gide TN, Quek C, Menzies AM, Tasker AT, Shang P, Holst J, Madore J, Lim SY, Velickovic R, Wongchenko M, Yan Y, Lo S, Carlino MS, Guminski A, Saw RPM, Pang A, McGuire HM, Palendira U, Thompson JF, Rizos H, Silva IPD, Batten M, Scolyer RA, Long GV, Wilmott JS. distinct immune cell populations define response to anti-pd-1 monotherapy and Anti-PD-1/Anti-CTLA-4 Combined Therapy. Cancer Cell 2019;35(2):238-55 e6.

4. Cloughesy TF, Mochizuki AY, Orpilla JR, Hugo W, Lee AH, Davidson TB, Wang $A C$, Ellingson BM, Rytlewski JA, Sanders CM, Kawaguchi ES, Du L, Li G, Yong WH, Gaffey SC, Cohen AL, Mellinghoff IK, Lee EO, Reardon DA, O'Brien BJ, Butowski NA, Nghiemphu PL, Clarke JL, Arrillaga-Romany IC, Colman H, Kaley TJ, de Groot JF, Liau LM, Wen PY, Prins RM. Neoadjuvant anti-PD-1 immunotherapy promotes a survival benefit with intratumoral and systemic immune responses in recurrent glioblastoma. Nat Med. 2019;25(3):477-86.

5. Riaz N, Havel JJ, Makarov V, Desrichard A, Urba WJ, Sims IS, Hodi FS, MartinAlgarra S, Mandal R, Sharfman WH, Bhatia S, Hwu WJ, Gajewski TF, Slingluff CL, Jr., Chowell D, Kendall SM, Chang H, Shah R, Kuo F, Morris LGT, Sidhom JW, Schneck JP, Horak CE, Weinhold N, Chan TA. Tumor and microenvironment evolution during immunotherapy with nivolumab. Cell 2017;171(4):934-49 e16.

6. Hugo W, Zaretsky JM, Sun L, Song C, Moreno BH, Hu-Lieskovan S, Berent-Maoz B, Pang J, Chmielowski B, Cherry G, Seja E, Lomeli S, Kong X, Kelley MC, Sosman JA, Johnson DB, Ribas $A$, Lo RS. Genomic and transcriptomic features of response to anti-PD-1 therapy in metastatic melanoma. Cell 2016;165(1):35-44.

7. Rosenberg JE, Hoffman-Censits J, Powles T, van der Heijden MS, Balar AV, Necchi A, Dawson N, O'Donnell PH, Balmanoukian A, Loriot Y, Srinivas S, Retz MM, Grivas P, Joseph RW, Galsky MD, Fleming MT, Petrylak DP, Perez-Gracia JL, Burris HA, Castellano D, Canil C, Bellmunt J, Bajorin D, Nickles D, Bourgon R, Frampton GM, Cui N, Mariathasan S, Abidoye O, Fine GD, Dreicer R. Atezolizumab in patients with locally advanced and metastatic urothelial carcinoma who have progressed following treatment with platinum-based chemotherapy: a single-arm, multicentre, phase 2 trial. Lancet. 2016;387(10031):1909-20.

8. Thorsson V Gibbs DL, Brown SD, Wolf D, Bortone DS, Ou Yang TH, Porta-Pardo E, Gao GF, Plaisier CL, Eddy JA, Ziv E, Culhane AC, Paull EO, Sivakumar IKA, Gentles AJ, Malhotra R, Farshidfar F, Colaprico A, Parker JS, Mose LE, Vo NS, Liu J, Liu Y, Rader J, Dhankani V, Reynolds SM, Bowlby R, Califano A, Cherniack AD, Anastassiou D, Bedognetti D, Mokrab Y, Newman AM, Rao A, Chen K, Krasnitz A, Hu H, Malta TM, Noushmehr H, Pedamallu CS, Bullman S, Ojesina Al, Lamb A, Zhou W, Shen H, Choueiri TK, Weinstein JN, Guinney J, Saltz J, Holt RA, Rabkin CS, Cancer Genome Atlas Research N, Lazar AJ, Serody JS, Demicco EG, Disis ML, Vincent BG, Shmulevich I. The Immune Landscape of Cancer. Immunity 2018:48(4):812-30 e14

http://dx.doi.org/10.1136/jitc-2020-SITC2020.0075

\section{POTENTIAL MECHANISMS OF RESISTANCE IDENTIFIED THROUGH ANALYSIS OF MULTIPLE BIOMARKERS IN IMMUNE HOT NON-RESPONDERS WITH NON-SMALL CELL LUNG CANCER (NSCLC) TREATED WITH TISLELIZUMAB}

\begin{abstract}
${ }^{1}$ Jayesh Desai*, ${ }^{2}$ Qing Zhou, ${ }^{3}$ Sanjeev Deva, ${ }^{4} J u n$ Zhao, ${ }^{5}$ Jie Wang, ${ }^{6}$ Wei Tan, ${ }^{7}$ Xiaopeng Ma, ${ }^{7}$ Yun Zhang, ${ }^{7}$ Zhirong Shen, ${ }^{6}$ Xikun Wu, ${ }^{6}$ Shiangjiin Leaw, ${ }^{7}$ Juan Zhang, ${ }^{2} Y_{i}$-Long Wu. ${ }^{1}$ Peter MacCallum Cancer Centre, Melbourne, Australia; ${ }^{2}$ Guangdong Provincial People's Hospital, Guangzhou, China; ${ }^{3}$ Auckland City Hospital, Auckland, New Zealand; ${ }^{4}$ Chinese Academy of Medical Sciences, Beijing, China; ${ }^{5}$ Beijing Cancer Hospital, Beijing, China; ${ }^{6}$ Beigene (Shanghai) Co., Ltd., Shanghai, China; ${ }^{7}$ Beigene (Beijing) Co., Ltd., Beijing, China
\end{abstract}

Background Tislelizumab, an anti-PD-1 monoclonal antibody, has demonstrated clinical benefit for patients with NSCLC. The underlying response and resistance mechanisms to tislelizumab treatment remain unknown.

Methods Baseline tumor samples from 59 nonsquamous (NSQ) and 41 squamous (SQ) NSCLC patients treated with tislelizumab monotherapy (NCT02407990 and NCT04068519) were tested for gene mutations using large panel next generation sequencing and RNA expression using gene expression profiling (GEP; Precision Immuno-Oncology Panel, HTG Molecular
Diagnostics). GEP analyses of NSQ and SQ NSCLC were performed separately due to different gene expression patterns. Results The ORR, mPFS, and mOS in this pooled NSCLC cohort were 15.2\% (95\% CI: 9.0, 23.6), 4.1 months (95\% CI: $2.20,6.11$ ), and 15.1 months (95\% CI: 11.20, NE), respectively, with a median study follow-up of 15.3 months (95\% CI: 14.06, 15.90). Non-responders (NRs) exhibited distinct tumor and immune gene signature profiles and could be clustered into two subgroups: NR1 and NR2. Compared with responders, NR1 had elevated cell cycle signatures in both NSQ $(P=0.2)$ and SQ $(\mathrm{P}=0.03)$ cohorts, and a trend of decreased inflamed gene signature profiles. However, NR2 showed comparable or even higher tumor inflammation (18-gene), and CD8 + T-cell signature scores in both NSQ and SQ cohorts and could be classified as immune hot. To explore the resistance mechanisms of immune hot NRs, differentially expressed gene analyses between immune hot NR2 and responders were performed. M2 macrophage and Treg signature scores were higher in NR2 in both NSQ (M2, P=0.05; Treg, $\mathrm{P}=0.03$ ) and SQ (M2, $\mathrm{P}=0.05$ [subgroup of NR2]; Treg, $\mathrm{P}=0.03$ ) cohorts; significantly higher expression of immune regulatory genes included PIK3CD, CCR2, CD244, IRAK3, and MAP4K1 $(\mathrm{P}<0.05)$ in NSQ and PIK3CD, CCR2, CD40, CD163, and MMP12 $(\mathrm{P}<0.05)$ in SQ. Significantly higher epithelial-mesenchymal transition (EMT) and angiogenesis gene expression, including SNAI1, FAP, VEGFC, and TEK $(\mathrm{P}<0.05)$ genes, were also observed in SQ NR2. Moreover, gene mutation analysis identified seven immune hot NR patients harboring either driver mutations (RET fusion, ROS1 fusion, BRAF, and PIK3CA amp) or well-established resistance mutations (loss of function mutation in JAK2, STK11, and MDM2 amplification).

Conclusions Despite the presence of immune hot features, a subgroup of tislelizumab NRs with NSCLC were identified. High levels of immune suppressive factors, such as M2 macrophage and Treg signatures, angiogenesis, and EMT genes, as well as the existence of driver/resistance mutations, may indicate mechanisms of resistance of immune hot NRs, highlighting potential novel treatment targets.

Acknowledgements Editorial assistance was provided by Agnieszka Laskowski, PhD, and Elizabeth Hermans, PhD (OPEN Health Medical Communications, Chicago, IL), and funded by the study sponsor.

Trial Registration NCT02407990 and NCT04068519

http://dx.doi.org/10.1136/jitc-2020-SITC2020.0076

\section{ASSOCIATION BETWEEN PROGRAMMED DEATH-LIGAND 1 (PD-L1) EXPRESSION AND GENE SIGNATURES OF RESPONSE OR RESISTANCE TO TISLELIZUMAB MONOTHERAPY IN HEPATOCELLULAR CARCINOMA (HCC)}

${ }^{1}$ Ming-Mo Hou, ${ }^{2}$ Kun-Ming Rau, ${ }^{3}$ Yoon-Koo Kang, ${ }^{4}$ Jong-Seok Lee, ${ }^{5}$ Hongming Pan, ${ }^{6}$ Ying Yuan, ${ }^{7}$ Cunjing Yu, ${ }^{7}$ Yun Zhang, ${ }^{7}$ Xiaopeng Ma, ${ }^{7}$ Xikun Wu, ${ }^{7}$ Xin Li, ${ }^{8}$ Katie Wood, ${ }^{9}$ Chia-Jui Yen*. 'Chang Gung Memorial Hospital, Taoyuan, Taiwan, Province of China; ${ }^{2}$ Kaohsiung Chang Gung Memorial Hospital, Kaohsiung City, Taiwan, Province of China; ${ }^{3}$ Asan Medical Center, Seoul, Korea, Republic of; ${ }^{4}$ National University Bundang Hospital, Seongnam-si, Korea, Republic of; ${ }^{5}$ Sir Run Run Shaw Hospital, Hangzhou, China; ${ }^{6}$ Second Affiliated Hospital Zhejiang, Hangzhou, China; ' BeiGene (Beijing) Co., Ltd., Beijing, China; ${ }^{8}$ BeiGene USA, Inc., San Mateo, CA, USA; ${ }^{9}$ National Cheng Kung University Hospital, Tainan City, Taiwan, Province of China

Background PD-1/L1 inhibitors are treatment options for patients with HCC who have progressed after first-line 


\section{University Library}

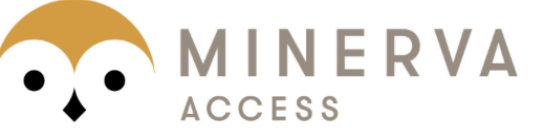

A gateway to Melbourne's research publications

Minerva Access is the Institutional Repository of The University of Melbourne

\section{Author/s:}

Desai, J;Zhou, Q;Deva, S;Zhao, J;Wang, J;Tan, W;Ma, X;Zhang, Y;Shen, Z;Wu, X;Leaw, S;Zhang, J;Wu, Y-L

Title:

POTENTIAL MECHANISMS OF RESISTANCE IDENTIFIED THROUGH ANALYSIS OF MULTIPLE BIOMARKERS IN IMMUNE HOT NON-RESPONDERS WITH NON-SMALL CELL LUNG CANCER (NSCLC) TREATED WITH TISLELIZUMAB

Date:

2020-11-01

\section{Citation:}

Desai, J., Zhou, Q., Deva, S., Zhao, J., Wang, J., Tan, W., Ma, X., Zhang, Y., Shen, Z., Wu, X., Leaw, S., Zhang, J. \& Wu, Y. -L. (2020). POTENTIAL MECHANISMS OF RESISTANCE IDENTIFIED THROUGH ANALYSIS OF MULTIPLE BIOMARKERS IN IMMUNE HOT NONRESPONDERS WITH NON-SMALL CELL LUNG CANCER (NSCLC) TREATED WITH TISLELIZUMAB. [Abstract]. JOURNAL FOR IMMUNOTHERAPY OF CANCER, 8 (Suppl 3), pp.A47-A47. https://doi.org/10.1136/jitc-2020-SITC2020.0076.

Persistent Link:

http://hdl.handle.net/11343/280254

License:

CC BY NC ND 